
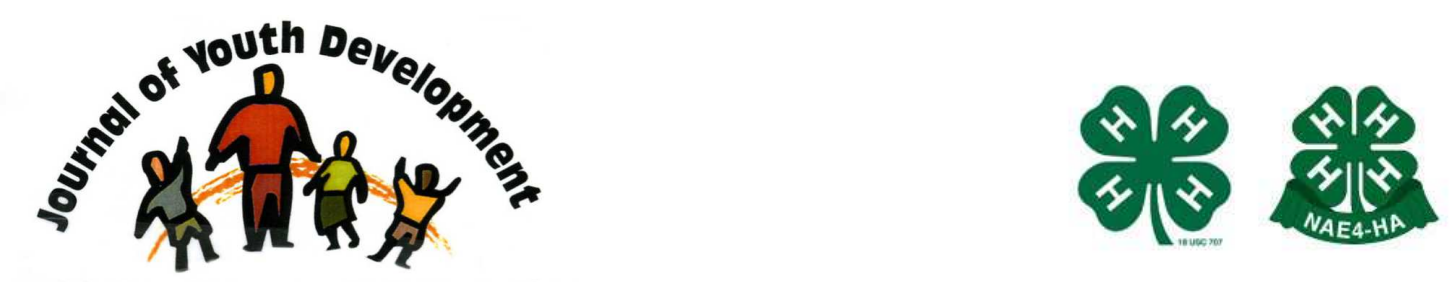

Bridging Research \& Practice

\title{
S.E.A.L.S.+PLUS \\ Self-Esteem and Life Skills
}

\author{
Patricia A. Dawson \\ Oregon State University \\ Pendleton, OR
}

patricia.dawson@oregonstate.edu 


\title{
JOURNAL OF YOUTH DEVELOPMENT \\ bridging research and practice

\section{S.E.A.L.S.+PLUS \\ Self-Esteem and Life Skills}

Patricia A. Dawson

Oregon State University

\begin{abstract}
S.E.A.L.S.+PLUS is an activity book and CD-ROM featuring over 75 reproducible self-esteem and mental wellness lessons for youth ages 12-18. Topics include segments on Goal Setting, Stress Management, Health Awareness, Anger Management, Communication Skills and more. Youth professionals will appreciate this well designed, interactive resource as they engage youth in positive skill development.
\end{abstract}

\section{Review}

A key element for many youth development programs focuses on the development of practical life skills (Perkins \& Borden, 2003). S.E.A.L.S.+PLUS: Self-Esteem and Life Skills (Korb, Azok \& Leutenberg, 1992) is a reproducible activity book addressing mental wellness and life-skills education for youth aged 12-18. The material is particularly useful for breakout classes at Leadership Conferences and Teen Retreats and is designed to save educators time in preparing lessons for individual or group activities.

Topics covered include:

- Anger Management

- Assertion

- Awareness

- Communication Skills

- Coping Skills

- Emotion Identification

- Goal Setting

- Health Awareness

- Money Management

- Problem Solving 
- Risk Taking

- Self-Esteem

- Stress Management

- Support Systems

- Time Management

- Values Clarification

Several activities and engaging, age-appropriate handouts have been developed for each of the above topics. The material is designed to help middle and high school students achieve increased self-esteem and learn important life lessons. In addition a 15 page facilitator's bonus section includes supplemental role-plays.

The book contains over 75 handouts, role-play guidelines, a glossary and a CD-ROM for ease in printing selected handouts. The book with CD-ROM is reasonable priced at $\$ 60$ and may be ordered on line at www.At-Risk.com.

\section{References}

Korb, K., Azok, S., \& Leutenberg, E. (1992). SEALS+PLUS: Self-Esteem and Life Skills reproducible activity-based handouts created for teachers and counselors. Wellness Reproductions Incorporated. Beachwood, $\mathrm{OH}$.

Perkins, D.F., \& Borden, L.M. (2003). Key elements of community youth development in F.A. Villarruiel et al., Community youth development. Thousand Oaks, CA: Sage Publications.

(C) Copyright of Journal of Youth Development Bridging Research and Practice. Content may not be copied or emailed to multiple sites or posted to a listserv without copyright holder's express written permission. However, users may print, download or email articles for individual use. 